\title{
I Studied Abroad, therefore I am a Global Citizen? An Initial Study on Relationship between Global Citizenship and International Mobility Experiences
}

\section{Abstract}

In the current era of globalization, higher education is expected not only to educate people to work locally in their home country, but also to foster "global citizens" who can play important roles internationally. In recent years, curriculum design and reform efforts at the higher education level in Taiwan have sought to encourage young people to move out of their comfort zones and connect with people from different cultural and social backgrounds to further expand their international perspectives and intercultural competencies. The main aim of the current research is to explore if students' international mobility experiences - in this context, studying abroad-would affect their attitudes toward elements of global citizenship and identification as global citizens. This research included an online survey to recruit 69 Taiwanese participants with study abroad experiences at the higher education level to understand their identification as global citizens, their attitudes toward elements of global citizenship, and their interpretations of how studying abroad might affect their perceptions of global citizenship. The results from the regression analysis indicate that participants with international mobility experiences tend to see themselves as global citizens and have stronger agreements toward elements of global citizenship.

Key words: Global citizenship, international mobility, Taiwanese, higher education

* Assistant Research Fellow, National Academy for Educational Research (R.O.C.) 


\section{I . Introduction}

Different countries try to prepare their citizens to be "global citizens" based on their policy documents. However, the content and meanings of global citizenry and how to act as a global citizen is a more delicate issue than it seems on paper. This study discusses issues related to global citizenship and students' international mobility, using Taiwan as a case study, to further understand students' perceptions of their identification as a global citizen. The Taiwanese government announced policies and strategic plans such as "Developing $21^{\text {st }}$ Century Competencies for Our New Generation: a white paper on international education for primary and secondary schools"(MOE, 2011) and "Promoting Youth Students Global Mobility Plan"(MOE, 2015) in order to prepare youth and students with international awareness and competence as global citizens in the living world. Part of the Taiwanese government's strategic plans is to promote students' global citizenship through various options to become mobile internationally. However, not much research has been conducted in the field to assess the performance of such policies and strategic plans. This research, therefore, adopted most of the items from Stephen Reysen's Global Citizen Scale and added items to design an online global citizen survey in Chinese to recruit Taiwanese who have studied abroad at the higher education level in order to explore if their study abroad experiences correlate with their attitudes toward the elements of global citizenship and their identification as global citizens.

\section{П. Literature Review}

\section{Definitions and Elements of Global Citizenship}

Defining a global citizen is not easy to do. A global citizen is defined based on awareness, caring, the embracing of cultural diversity, promotion of social justice and sustainability, and a sense of responsibility to act (Reysen, Larey, \& Katzarska-Miller, 2012). Recent empirical research conducted by Reysen and Katzarska-Miller (2013a) has shown that greater identification, or psychological connection, with global citizens predicts greater endorsement of prosocial values, including intergroup empathy (felt connection and concern for people outside one's ingroup), valuing of diversity (appreciation and interest of diverse cultures), 
social justice (endorsement of human rights and equitable treatment of others), environmental sustainability (concern for and connection to the natural environment), intergroup helping (desire to aid others outside one's ingroup), and a responsibility to act (duty to act for the betterment of the world). These results are consistent with a social identity perspective (Tajfel \& Turnmer, 1979; Turner, Hogg, Oakers, Reicher, \& Wetherell, 1987), as greater identification with the global citizen group predicts greater adherence to the group's content or meaning (i.e., prosocial values). Antecedents to global citizenship identification include the perception that valued others (e.g., friends, family) in one's normative environment prescribe being a good citizen and one's perceived global awareness (i.e., knowledge of and connection to the world) (Reysen \& Katzerska-Miller, 2013b).

Theorists have contributed to the meaning of global citizenship in the contemporary world by using different methods and different emphases. As Dower (2003) mentioned, although we all have universal rights and global responsibilities, we are not born as global citizens. Dower (2003) agreed that global citizenship involves some kind of self-identification as a global citizen - specifically, active engagement. Global citizenship is not an identity given officially, such as national citizenship; rather, it is an identity recognized through individual behavior and attitude (Chen, 2011). Davies (2006) argued that global citizenship is based on rights, responsibilities, and action.

\section{Practices of Global Citizenship}

Schattle (2008) interviewed people around the world about their perceptions as global citizens and their practices of global citizenship. He found that three primary conceptsawareness, responsibility, and participation-were central in the minds of the respondents in their understandings of global citizenship, which were notably convergent with their definitions of both global citizenship and citizenship as well as being mutually dependent on each other for their full power.

The intertwined concepts of awareness, responsibility, and participation together provide a vivid representation of the multiple personal qualities to which global citizens aspire (Shattle, 2008), including being comfortable in the "universe" of one's own skin while navigating different settings; understanding how important issues are interconnected; erasing distinctions between "us" and "them," or insiders and outsiders; refusing to believe that one 
has a restricted, finite personal identity; thinking of oneself as a stakeholder, even a steward, in protecting the earth and its natural resources; and thinking of proximity to others and to global problems as not defined or constrained by geographical boundaries.

According to Schattle (2008), awareness, responsibility, and participation deserve special attention as primary concepts of global citizenship for three reasons. These three concepts have commonly emerged as central in the thinking of those interviewed as far as what global citizenship requires and why the idea of global citizenship is seen as worthwhile. Taken together, the concepts of awareness, responsibility, and participation also emphasize the recognition of global interdependence-a key consolidating idea within global citizenship discourse in its own right.

The concepts of awareness and participation show how numerous self-described global citizens do indeed display motivation for sustained political involvement, while the concept of awareness further reveals how global citizens are able to look at issues from a multiplicity of vantage points and perspectives (Schattle, 2008). The concept of responsibility shows how both principled decision making and notions of solidarity across humanity factor into moral accountability that many global citizens accept personally for themselves, regardless of the evolution of global governing institutions (Schattle, 2008).

In addition to the three identified concepts of global citizenship, Shattle (2008) found that concepts of cross-cultural empathy, personal achievement, and international mobility stop short of operating as central organizing principles in the body of thought surrounding the term global citizenship. In particular, empathy may be as close as we get and requires some elaboration as it is dealt with variously within the citizenship and intercultural literature (Killick, 2011). A "successful" intercultural encounter has the potential to bring the distant figure into the life world, where empathic knowing is richest and has the potential to extend from the known individual to his or her group, diminishing both chauvinism and romanticism in future intercultural encounters (Killick, 2011).

\section{Promoting Students' International Mobility to Prepare Global Citizens}

Educational leaders must consider that 21st - century students have to prepare to live and work in an increasingly complex world. An educated person may need to develop the knowledge base, skills, and attitudes required to function in and contribute to a global society 
(AACTE, 2010). In addition, global citizenship education proponents (Selby, 1999; Pike, 2008; Young, 2010; Tawil, 2013) have stressed the importance of teaching students to view the dynamic interconnectedness of relationships in the world to engender global citizenship.

Global citizenship appropriately designed in educational programs can be as basic and immediate to help youngsters understand the earth around them. Different educational initiatives promoting global citizenship emphasize various aspects, including for developing analytical and communication skills, and for encouraging cross-cultural dialogue and empathy, and etc. Mutual respect and the appreciation of differences serve as primary goals to be attained, along with viewing the idea of global citizenship as an "inner nobility" to be nurtured within hearts and minds (Schattle, 2008).

Schattle (2009) identified five ways individuals move toward becoming global citizens: through experiences during childhood, immigration experiences, political and social activism, professional opportunities, and educational programs. He concluded that "traveling abroad to participate in educational programs has served a pivotal step in the lives of many self-described global citizens" (p. 15).

Universities have a legitimate responsibility to prepare their students for life in these futures; where life refers to authentic experiences and the will and predomination among policy setters or university administrators; meanwhile, it is far from clear where much of the academy sits (Killick, 2011). Currently, the new trend of preparing local students to be global citizens focuses on international experiences. Generally, research findings tend to be highly positive about the "legion" benefits (Lenz \& Wister, 2008, p. 84) of international mobility and to reflect the very pervasive anecdotal standpoints of experienced international education.

The United States is hosts the most international students and has started to pay attention to nurturing local talents to be equipped with global awareness and intercultural sensitivities in recent years. In 2004, the Senator Paul Simon initiated the Abraham Lincoln Study Abroad Fellowship, and the Senate named the year 2006 as "studying abroad year" (NAFSA, 2006). Along with Senator Simon's Study Abroad Foundation Act, the Senate suggested that the federal government financially aid college students' studies abroad in order to ensure that American students [can] learn foreign languages and international knowledge for further improving global competencies of the U.S. (Tarrant, 2010). In addition, most higher education institutions are aware that the nation needs its future citizens to be equipped with sensitivity to global issues. Therefore, higher education institutions are increasing the number of 
students studying abroad to respond to this trend. Ivy League schools, including Harvard University, have initiated curriculum reforms and require participation in short-term study abroad programs to graduate (Tarrant, 2010).

Meanwhile, in 2012, the government in Hong Kong extended college degree terms from three to four years. The current curriculum design in college years also integrated diverse experiential learning, including study abroad, work study, capstone projects, and community-based service learning. Students can be trained through experiential learning to be holistic with critical thinking, problem solving, team establishment, intercultural sensitivity, and responsibility as global citizens (Finkelstein \& Walker, 2008).

A major mobility survey conducted in the United Kingdom (Sussex Centre for Migration Research and Centre for Applied Population Research, 2004) found that academic staff frequently reported that returning students were "transformed," with "increased maturity, self-confidence, linguistic confidence, better academic performance, cultural understanding and a clear purpose in life" (Hadis, 2005, p. 46). Hadis' summary of the findings of several research projects is typical. The consensus is that "participants in study abroad programs acquire global-mindedness, grow intellectually, and develop personally" (Hadis, 2005, p. 3). However, in Hadis' own experiences as study abroad advisor, he found that "almost without exception, every student I have interviewed upon their return from abroad has expressed the opinions that the experience $\cdots$ has been the most meaningful and rewarding one in their lives so far" $^{\prime \prime}$ (p. 7).

\section{Taiwanese Government Plans to Prepare Global Citizens through International Mobility Experiences}

In "The Ministry of Education Talent Training White Paper," the government stated that in addition to equipping Taiwanese students with professional skills, they need to prepare their language skills, multicultural literacy, global view, and international mobility to become good global citizens (MOE, 2013). As indicated in this white paper, the government aims to prepare future talents with six abilities, including global mobility, employability, innovation ability, information ability, cross-border ability, and civil ability. The strategies to do so include encouraging students to participate in short-term study abroad programs, international volunteer groups, working holidays, international internships, etc., at the higher 
education level (MOE, 2013). The current goal is to send 20,000 students abroad in 2016.

Yet the Taiwanese are currently not very international, from local news programs to the daily environment. A 2006 survey entitled "Taiwanese view the world" conducted by a reputable and credible magazine (Vision Magazine, 2006) found that Taiwanese wanted to know more about international news, but most of the respondents received their international news from local media, which mainly distribute international news on disasters, wars, and financial conditions in the world. The partial news narrowed, not broadened, Taiwanese views of the world. When asked if they would pay $1 \%$ more tax to help people in underdeveloped countries, $40 \%$ of the Taiwanese respondents said no, compared to more than $70 \%$ of respondents from Turkey, Japan, Mainland China, Germany, Australia, and India who said yes. In addition, the Taiwanese identified themselves as a poor country on the periphery of the world stage. Approximately $56.6 \%$ of Taiwanese participants in the survey saw themselves as inferior to people in other countries and 36\% defined Taiwan as a poor country. Furthermore, respondents from the survey indicated that the government and media play the smallest roles in promoting Taiwan's international image in the world, while NGOs and NPOs play better roles for this part.

In order to respond to the lack of a global view in Taiwanese society, the government has tried different approaches to encourage youth to study abroad and promote their international mobility. However, it is easier to send out students than to prove the application works for promoting students' global citizenship. The lack of relevant research regarding Taiwanese students' global citizenship consciousness might cause a gap between policy purpose and practices. Therefore, this research aims to recruit Taiwanese students who have been studying abroad during higher education studies to understand their identification as a global citizen, their attitudes toward elements of global citizenship, and the correlation between study abroad experiences and global citizenship. 


\section{Methodology}

\section{Participants}

According to the main goals of this research, the author conducted an online global citizen survey using snowball sampling. The author sent links to the survey to Taiwanese with study abroad experiences, including short-term and long-term experiences, during their higher education studies and encouraged them to send the invitation email to their acquaintances with study abroad experiences. In total, 69 valid responses were received from 53 female participants and 16 male participants.

\section{Measures}

As Chui and Leung (2014) pointed out, it is important that norms, responsibilities, and attitudes be measured in any survey designed to measure global citizenship given that only by recognizing the interconnectedness of the world-of being part of this global world-can a sense of obligation toward the international community in a rights-and-responsibility manner make sense. Therefore, in addition to asking for participants' basic information, including gender, age, and current residential location, the survey also asked about their period of study abroad, nations visited, the reasons for choosing to study abroad, and definition of "global citizen."

Stephen Reysen's online Global Citizen Survey includes 23 items to measure participants' attitudes toward the elements of global citizenship and their interpretation if their past study abroad experiences impact their global citizenship perception, based on a 5-point Likert scale ranging from "strongly disagree" to "strongly agree." Reysen, Katzarska-Miller, Salter, \& Hirko (2014) has used the Global Citizen Survey to examine the outcomes of an extinction threat to one's nation on global citizenship identification and related prosocial values. In addition, Katzarska-Miller, Reysen, Kamble, \& Vithoji (2012) used this survey to explore cross-national differences of the definition of global citizenship, global citizenship identification, and endorsement of pro-social values. The Global Citizen Survey is used broadly in different research regarding global citizenship and the current study adopted 18 items and translated them into Chinese for participants to answer. These items included four 
that assessed the perception that others in one's normative environment valued being a global citizen. Three items assessed global awareness, three items assessed global responsibility, three items assessed global participation, and five items assessed cross-cultural empathy. In addition, the author added five questions about participants' perceptions regarding how their study abroad experiences impact their views of and interests in global issues, including global politics, global economics, and global cultures.

\section{Results}

\section{Descriptive Statistics Analysis}

I am a global citizen, but $\cdots$. Participants were asked about their own identification as a global citizen; the mean of their rating score was approximately 3.44 at category 1 in Table 1, indicating that they generally agreed with the statement that "I strongly define myself as a global citizen." However, the respondents did not think that their families or even Taiwanese society thought that "being a global citizen [was] desirable."

I am closely connected with people in other countries. Participants' responses to the questions in the global awareness category, category 2 in Table 1, showed an interconnection to people in other countries and agreement with the statement that their actions in the local environment might affect people in other countries and it is important to conserve natural resources for people on earth to share together.

I care about people's well-being in other countries. Participants' responses to global responsibility items, category 3 in Table 1, showed that Taiwanese participants considered other people's well-being with regard to human assistance, human rights, etc.

I am willing to actively participate in global issues. According to the results from category 4 in Table 1, Taiwanese participants indicated that they are willing to help people in other countries, which might be affected by the media sharing disaster news from around the world. When Taiwanese think about global issues, they consider people in need.

I want to know other cultures in the world In the category 5, participants showed more interest in learning about other cultures and understanding people from different cultural backgrounds. 


\section{My study abroad experience makes me want to learn more about people from other cultures in the} world When participants were asked about their interpretation of the relationship between their past study experiences and elements in global issues, category 6 in Table 1, they indicated that their worldview had opened significantly, they wanted to learn more about other cultures, and they were willing to reach people from other backgrounds.

\section{$<$ Table 1> Participants' Responses to Different Categories}

\begin{tabular}{|c|c|c|}
\hline Category 1 & $\begin{array}{l}\text { Perception that self and others in one's normative } \\
\text { environment valued being a global citizen }\end{array}$ & $\begin{array}{l}\text { Mean } \\
\text { (on a scale of } 1 \text { to } 5 \text { ) }\end{array}$ \\
\hline Item 1 & I strongly define myself as a global citizen & 3.4412 \\
\hline Item 2 & $\begin{array}{l}\text { My family thinks that being a global citizen is } \\
\text { desirable }\end{array}$ & 2.7826 \\
\hline Item 3 & $\begin{array}{l}\text { My friends think that being a global citizen is } \\
\text { desirable }\end{array}$ & 3.2464 \\
\hline Item 4 & $\begin{array}{l}\text { Taiwanese society thinks that being a global } \\
\text { citizen is desirable }\end{array}$ & 2.8551 \\
\hline Category 2 & Global Awareness & $\begin{array}{l}\text { Mean } \\
\text { (on a scale of } 1 \text { to } 5 \text { ) }\end{array}$ \\
\hline Item 1 & $\begin{array}{l}\text { I am aware that my actions in my local } \\
\text { environment may affect people in other countries }\end{array}$ & 4.2464 \\
\hline Item 2 & $\begin{array}{l}\text { I believe that I am connected to people in other } \\
\text { countries, and my actions can affect them }\end{array}$ & 3.8986 \\
\hline Item 3 & $\begin{array}{l}\text { People have a responsibility to conserve natural } \\
\text { resources to foster a sustainable environment }\end{array}$ & 4.6667 \\
\hline Category 3 & Global Responsibility & $\begin{array}{l}\text { Mean } \\
\text { (on a scale of } 1 \text { to } 5 \text { ) }\end{array}$ \\
\hline Item 1 & $\begin{array}{l}\text { Those countries that are well off should help } \\
\text { people in countries who are less fortunate. }\end{array}$ & 4.0145 \\
\hline Item 2 & $\begin{array}{l}\text { Basic services such health care, clean water, food, } \\
\text { and legal assistance should be available to } \\
\text { everyone, regardless of what country they live in }\end{array}$ & 4.3676 \\
\hline Item 3 & $\begin{array}{l}\text { Natural resources should be used primarily to } \\
\text { provide for basic needs rather than material } \\
\text { wealth }\end{array}$ & 4.6176 \\
\hline Category 4 & Global Participation & $\begin{array}{l}\text { Mean } \\
\text { (on a scale of } 1 \text { to } 5 \text { ) }\end{array}$ \\
\hline Item 1 & $\begin{array}{l}\text { If I had the opportunity, I would help others who } \\
\text { are in need, regardless of their nationality }\end{array}$ & 4.4638 \\
\hline Item 2 & $\begin{array}{l}\text { Being actively involved in global issues is my } \\
\text { responsibility }\end{array}$ & 3.8529 \\
\hline Item 3 & $\begin{array}{l}\text { It is my responsibility to understand and respect } \\
\text { cultural differences across the globe to the best } \\
\text { of my abilities }\end{array}$ & 4.1739 \\
\hline
\end{tabular}




\begin{tabular}{|c|c|c|}
\hline Category 5 & Cross-cultural Empathy & $\begin{array}{l}\text { Mean } \\
\text { (on a scale of } 1 \text { to } 5 \text { ) }\end{array}$ \\
\hline Item 1 & $\begin{array}{l}\text { It is easy for me to put myself in someone else' s } \\
\text { shoes, regardless of what country they are from }\end{array}$ & 4.1618 \\
\hline Item 2 & $\begin{array}{l}\text { I am able to empathize with people from other } \\
\text { countries }\end{array}$ & 3.9420 \\
\hline Item 3 & $\begin{array}{l}\text { I would like to join groups that emphasize getting } \\
\text { to know people from different countries }\end{array}$ & 4.0870 \\
\hline Item 4 & $\begin{array}{l}\text { I keep myself informed of current issues and } \\
\text { news in the world }\end{array}$ & 3.9559 \\
\hline Item 5 & $\begin{array}{l}\text { I am interested in learning about the many } \\
\text { cultures that have existed in the world }\end{array}$ & 4.4203 \\
\hline Category 6 & $\begin{array}{l}\text { Participants' study abroad experiences and their } \\
\text { effects on global issues }\end{array}$ & $\begin{array}{l}\text { Mean } \\
\text { (on a scale of } 1 \text { to } 5 \text { ) }\end{array}$ \\
\hline Item 1 & $\begin{array}{l}\text { My worldview is more open because of my study } \\
\text { abroad experience }\end{array}$ & 4.3478 \\
\hline Item 2 & $\begin{array}{l}\text { I have a deeper understanding of global politics } \\
\text { that enhances my interest in participating }\end{array}$ & 3.9118 \\
\hline Item 3 & $\begin{array}{l}\text { I have deeper understanding of global economics } \\
\text { that enhances my interest in participating }\end{array}$ & 3.9851 \\
\hline Item 4 & $\begin{array}{l}\text { I have a deeper understanding of global cultures } \\
\text { that enhances my interest in making further } \\
\text { inquiries }\end{array}$ & 4.3284 \\
\hline Item 5 & $\begin{array}{l}\text { I am more willing to reach out to people who are } \\
\text { different from my own background }\end{array}$ & 4.3529 \\
\hline
\end{tabular}

\section{Correlation between Global Citizenship and International Mobility}

Having analyzed the descriptive statistics, the next analytical step is to examine the possible correlations among the categories. Table 2 shows positive significant correlations between participants' international mobility experiences and the elements of global citizenship. 
$<$ Table 2> Correlations among Categories on the Global Citizen Survey

\begin{tabular}{|c|c|c|c|c|c|c|}
\hline & & $\begin{array}{l}\text { Own } \\
\text { perception } \\
\text { of being } \\
\text { a global } \\
\text { citizen }\end{array}$ & $\begin{array}{l}\text { Global } \\
\text { awareness }\end{array}$ & $\begin{array}{l}\text { Global } \\
\text { responsibility }\end{array}$ & $\begin{array}{l}\text { Global } \\
\text { participation }\end{array}$ & $\begin{array}{l}\text { Cross- } \\
\text { cultural } \\
\text { empathy }\end{array}$ \\
\hline \multirow[t]{2}{*}{$\begin{array}{l}\text { Study } \\
\text { abroad } \\
\text { experience } \\
\text { and its } \\
\text { effects }\end{array}$} & $\begin{array}{l}\text { Pearson } \\
\text { correlation } \\
\text { Sig. } \\
\text { (2-tailed) }\end{array}$ & $\begin{array}{l}.366 * * \\
.003 * *\end{array}$ & $\begin{array}{l}.467 * * \\
.000 * *\end{array}$ & $\begin{array}{l}.375 * * \\
.003 * *\end{array}$ & $\begin{array}{l}.542 * * \\
.000 * *\end{array}$ & $\begin{array}{l}.615 * * \\
.000 * *\end{array}$ \\
\hline & $\mathrm{N}$ & 62 & 63 & 61 & 62 & 61 \\
\hline
\end{tabular}

**. Correlation is significant at the 0.01 level (2-tailed)

\section{Regression Analysis}

I studied (study) abroad, therefore I am a global citizen. The results of the regression analysis showed that, in the category of "own perception that self and others in one's normative environment valued being a global citizen" as the dependent variable, those participants who value study abroad experiences and their effects on global issues more tend to identify themselves as global citizens (Table 3).

$<$ Table 3>Regression Analysis on Global Citizen Identification and Other Related Categories

\begin{tabular}{rrrr}
\hline $\mathrm{R}$ & $\mathrm{R}$ Square & Adjusted R Square & Std. Error of the Estimate \\
\hline $.346^{\mathrm{a}}$ & .120 & .104 & .64963 \\
\hline
\end{tabular}

a. Predictors: (Constant), study abroad experiences and their effects on global issues

\section{I care about others in the world, I studied (study) abroad, therefore I closely interconnect with others} in the world The regression analysis showed that, when global awareness is the dependent variable, participants' global responsibility and study abroad experiences and their effects on global issues can predict whether they had such global awareness in global citizenship that might lead them to be global citizens (Table 4).

$<$ Table 4> Regression Analysis on Global Awareness and Other Related Categories

\begin{tabular}{rrrr}
\hline $\mathrm{R}$ & $\mathrm{R}$ Square & Adjusted R Square & Std. Error of the Estimate \\
\hline $.617^{\mathrm{a}}$ & .380 & .369 & .49400 \\
\hline $.673^{\mathrm{b}}$ & .453 & .432 & .46857 \\
\hline
\end{tabular}

a. Predictors: (Constant), global responsibility

b. Predictors: (Constant), global responsibility, study abroad experiences and their effects on global issues 
I am closely interconnected with other people in the world, therefore I have a stronger responsibility to take care of other people in the world The regression analysis demonstrated that, when global responsibility is the dependent variable, participants with stronger global awareness tend to take more responsibility for taking care of other people in the world that might lead them to be global citizens (Table 5).

$<$ Table 5> Regression Analysis on Global Responsibility and Other Related Categories

\begin{tabular}{crrr}
\hline $\mathrm{R}$ & $\mathrm{R}$ Square & Adjusted R Square & Std. Error of the Estimate \\
\hline $.617^{\mathrm{a}}$ & .380 & .369 & \\
\hline
\end{tabular}

a. Predictors: (Constant), global awareness

I empathize with others in the world and I am highly aware of my interconnected relationship with others in the world, therefore I am actively involved in global issues. The regression analysis showed that, when global participation is the dependent variable, participants' global awareness and cross-cultural empathy can predict if they would participate in global issues, which might lead them to become global citizens (Table 6).

$<$ Table 6> Regression Analysis on Global Participation and Other Related Categories

\begin{tabular}{rrrrr}
\hline \multicolumn{2}{c}{$\mathrm{R}$} & \multicolumn{2}{c}{ R Square } & \multicolumn{2}{c}{$\begin{array}{c}\text { Adjusted } \\
\text { R Square }\end{array}$} & \multicolumn{2}{c}{ Std. Error of the Estimate } \\
\hline $.734^{\mathrm{a}}$ & .539 & & .530 & .43956 \\
\hline $.761^{\mathrm{b}}$ & .580 & .564 & .42336 \\
\hline
\end{tabular}

a. Predictors: (Constant), cross-cultural empathy

b. Predictors: (Constant), cross-cultural empathy, global awareness

\section{Concluding Remarks}

The data indicated that Taiwanese who have studied abroad tend to identify themselves as global citizens; they also generally agree with the elements of global citizenship, which might lead them to become global citizens. As Chui and Leung (2014) found in their research, the positive results regarding the merits of intercultural experiences can be attributed to the fact that contact with and the impact of physical exposure to foreign cultures, values, and people-especially in a university campus setting-expose students to issues and viewpoints that they have never encountered before. 
If the Taiwanese government wants to promote students' international mobility experiences at the higher education level, it should consider these research findings in terms of the possible positive results that can be expected from policy application in the near future, such as support the short-term study abroad programs, to recognize foreign study's credits, and etc. The main finding from the research addresses the aim of the research that participants with previous study abroad experiences strengthen their identification as global citizens. In addition, an interesting finding from the research is that Taiwanese participants might not identify themselves as global citizens, even when they think and act as global citizens. This might be because Taiwanese are not familiar with the concepts of global citizenship, which could be improved through better global citizenship education taught at schools. 
References

AACTE (2010). 21 century knowledge and skills in educator preparation. Retrieved from http://www.p21.org/storage/documents/aacte_p21_whitepaper2010.pdf Chen, S (2011). Developing global citizenship: the effect of studying abroad. International Journal of Development Education and Global Learning, 3(3), 45-64.

Chui, W.H. \& Leung, E.W. (2014). Youth in a global world: attitudes towards globalization and global citizenship among university students in Hong Kong. Asia Pacific Journal of Education, 34(1), 107-124.

Davies, L. 2006. Global citizenship: Abstraction or framework for action? Educational Review, $58(1), 5-25$.

Dower, N. (2003). An introduction to global citizenship. Edinburgh: Edinburgh University Press. Finkelstein, M.J., \& Walker, E.M. (2008). The progress of Hong Kong's universities in implementing the 3-34 reforms: a status report on preparation and prospects. Hong Kong: The University of Hong Kong.

Hadis, B. F. (2005). Gauging the impact of study abroad: how to overcome the limitations of a single-cell design. Assessment \& Evaluation in Higher Education, 30(1), 3-19.

Killick, D. (2011). Seeing ourselves-in-the-world developing global citizenship through international mobility and campus community. Unpublished Doctoral dissertation at Leeds Metropolitan University, UK.

Lenz, W., \& Wister, J. (2008). Short-term abroad with long-term benefits. International Educator, 173), 84-87.

MOE (2011). Developing 21st century competencies for our new generation: a white paper on international education for primary and secondary schools (in Chinese). Taipei: MOE. MOE (2013). The ministry of education talent training white paper (in Chinese). Retrieved from http://www.edu.tw/userfiles/url/20150319185201/\%E6\%95\%99\%E8\%82\%B2\%E9\%8 3\%A8\%E4\%BA\%BA\%E6\%89\%8D\%E5\%9F\%B9\%E8\%82\%B2\%E7\%99\%BD\%E7\%9A\%A E\%E6\%9B\%B8.pdf

MOE (2015). Promoting youth students global mobility plan (in Chinese). Taipei: MOE. NAFSA: Association of International Education (2006). About us. Retrieved from http://www.nasfa.org 
Pike, G. (2008). Citizenship education in global context. Brock Education, 17, 38-49. Reysen S (2013). Global citizen scale.

Retrieved from https://sites.google.com/site/stephenreysen/psychology-scales.

Reysen, S., Larey, L. W., \& Katzarska-Miller, I. (2012). College course curriculum and global citizenship. International Journal of Development Education and Global Learning, 4, 24-29.

Katzarska-Miller, I., Reysen, R., Kamble, S., \& Vithoji, N. (2012). Cross-national differences in global citizenship: comparison of Bulgaria, India, and the United States. Journal of Globalization Studies, 3(2), 166-183.

Reysen, S., \& Katzarska-Miller, I. (2013a). A model of global citizenship: antecedents and outcomes. International Journal of Psychology, 48, 858-870.

Reysen, S., \& Katzarska-Miller, I. (2013b). Intentional worlds and global citizenship. Journal of Global Citizenship \& Equity Education, 3(1), 34-52.

Reysen, S., Katzarska-Miller, I., Salter, P., \& Hirko, C (2014). Blurring group boundaries: the impact of subgroup threats on global citizenship. Cultural Encounters, Conflicts, and Resolutions, 1(2), 1-23.

Schattle, H. (2008). Global citizenship in theory and practice. In: Lewin, Ross (Ed.). The Handbook of Practice and Research in Study Abroad Higher education and the quest for global citizenship (pp. 3-20). New York, NY: Routledge.

Schattle, H. (2009). The practices of global citizenship. New York: Rowman \& Littlefield.

Selby, D. (1999). Global education: towards a quantum model of environmental education. Canadian Journal of Environment, 4, 125-141.

Tajfel H., \& Turner, J.C. (1979). An integrative theory of intergroup conflict. In W. Austin \& S. Worchel (Eds.), The social psychology of intergroup relations (pp. 33-47). Monterey, CA: Brooks/Cole.

Tarrant, M.A. (2010). A conceptual framework for exploring the role of studies abroad in nurturing global citizenship. Journal of Studies in International Education, 14(5), 433-451.

Tawil, S. (2013). Education for 'global citizenship': a framework for discussion. UNESCO education and foresight (ERF) working paper series, 7. Retrieved from http://www.unesco.org/new/fileadmin/MULTIMEDIA/HQ/ED/pdf/PaperN7Edu cforGlobalCitizenship.pdf

Turner, J.C., Hogg, M.A., Oakes, P.J., Reicher, S.D., \& Wetherell, M. (1987). Rediscovering the social group: a self-categorization theory. Oxford: Blackwell. 
Vision Magazine (2006). Taiwanese view the world. Retrieved from http://www.gvm.com.tw/Boardcontent_12194_1.html

Young, J.M. (2010). Problems with global education: conceptual contradictions. The Alberta Journal of Educational Research, 56, 143-156.

* Received January 1, 2016 / Revised March 20, 2016 / Accepted April 30, 2016

* Chen-Wei Chang, PhD: Assistant Research Fellow, Research Center for Educational System and Policy, National Academy for Educational Research, Taiwan (R.O.C.).

*E-mail: chenweichang@mail.naer.edu.tw 